\title{
Foreword: Dr Robert Hooke and the origins of engineering science
}

Alistair G. L. Borthwick MA, PhD, DSc, CEng, FICE

Professor of Engineering Science, University of Oxford, Oxford, UK

The following paper by Allan Chapman is an extended version of a lecture given by Dr Chapman at the Department of Engineering Science, University of Oxford, on 14 October 2007. The lecture was the first of a series to celebrate the centenary of the department and of the first Professor of Engineering Science at Oxford, Charles Frewin Jenkin.

Allan Chapman obtained a first class honours degree in history from Lancaster University in 1972, after which he undertook a DPhil at Wadham College, Oxford. His DPhil thesis Dividing the circle: a history of precise angular measurement in astronomy, 1500-1850 was published in 1990 (Chapman, 1990), followed by a second edition in 1995. Allan Chapman is a historian of science with particular interests in experimentation, precision mechanics and the wider circumstances concerning the lives and motivations of scientists. Robert Hooke has occupied a pivotal position in Chapman's interests for well over 30 years and, in 2005, he brought together his Hooke researches in England's Leonardo: Robert Hooke and the Seventeenth Century Scientific Revolution (Chapman, 2005). Allan Chapman is the author of eight books under his own name, along with three co-authored works, about 80 major academic papers and over 100 articles aimed at the public awareness of the importance of science and technology in history. $\mathrm{He}$ is also an active broadcaster in his field, having made several UK television documentary series, including a BBC programme on Hooke in 2003, as well as many radio programmes. In recognition of his work in the history of science, Allan Chapman received an honorary doctorate from the University of Central Lancashire in 2004 and was awarded an honorary DSc by the University of Salford in 2010.
To engineers, Robert Hooke is probably best known for his study of springs, relating the extension to the force applied, and for his elucidation of the engineering properties of catenary arches. But he also researched the properties of air, built a vacuum pump for Robert Boyle and devised many other scientific instruments such as the telescopes that he used for extensive and pioneering work in astronomy. His book on microscopy, Micrographia, caused a sensation when it was published in 1665 (Hooke, 1665). He was first Curator of Experiments to the Royal Society, Professor of Geometry at Gresham College, Surveyor to the City of London following the Great Fire of 1666 and an architect, collaborating with Sir Christopher Wren. The following paper describes the influence of Robert Hooke on engineering science through his innovations in measurement instruments, his contributions to mechanics, and his many inventions.

\section{REFERENCES}

Chapman A (1990) Dividing the Circle. The Development of Critical Angular Measurement in Astronomy 1500-1850. Praxis-Wiley, Chichester.

Chapman A (2005) England's Leonardo: Robert Hooke and the Seventeenth-Century Scientific Revolution. IoP Publishing, Bristol.

Hooke R (1665) Micrographia, or Some Physiological Descriptions of Minute Bodies Made by Magnifying Glasses. Printed by John Martyn and James Allestry on behalf of the Royal Society of London. 
Downloaded by [] on [25/04/23]. Copyright $\odot$ ICE Publishing, all rights reserved. 
Engineering and Computational Mechanics Volume 164 Issue EM4

Dr Robert Hooke and the origins of engineering science

Chapman
Proceedings of the Institution of Civil Engineers

Engineering and Computational Mechanics 164 December 2011 Issue EM4 Pages 189-205 http://dx.doi.org/10.1680/eacm.8.00060

Paper $\mathbf{8 0 0 0 6 0}$

Keywords: biography/history
Received 17/10/08

Published online 12/10/2011

Accepted 15/01/2010

ICE Publishing: All rights reserved
口

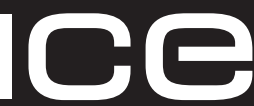

Institution of Civil Engineers

\section{Dr Robert Hooke and the origins of engineering science}

Allan Chapman MA, DPhil, FRAS, DSC, DUniv, FRAS

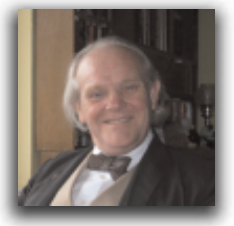

Member of the Faculty of History, University of Oxford and Wadham College, Oxford, UK

When John Aubrey described Hooke as the 'Greatest Mechanick this day in the World', he acknowledged Hooke's genius as an experimentalist. To Hooke, the whole of nature was a great machine or engine in motion, the deepest truths of which could be uncovered by means of ingeniously contrived instruments. In the 1650s, the 'ingeniosi' of the future Royal Society were beginning to revolutionise our sense of 'natural knowledge' and coming to envisage ways of applying it to 'the Relief of Man's Estate'. This paper describes Hooke's early life, his development of precision instruments such as the microscope, his Micrographia and its influence on engineering, his work on motion and elasticity, and his inventions, including the airpump, wheel barometer, hygrometer, spring watch, and various machine tools.

\section{Introduction}

When the historian, gossip and biographer of the eminent men and women of his age John Aubrey wrote the 'Brief Life' of his friend Robert Hooke in the late 1680s, he styled him the 'Greatest Mechanick this day in the World' (Aubrey, 1689: p. 165]. And what a deeply felt compliment was embedded in Aubrey's phrase, for not only was Hooke a long-standing friend but also a figure whom Aubrey hero-worshipped because of his prodigious learning and 'ingenuity' (Figure 1). But what did Aubrey mean by calling him a 'Mechanick'? It is true that, on one level, the word had a derogatory connotation, as seen in the comical rude mechanicals of Shakespeare's A Midsummer Night's Dream. But in the parlance of 300 years ago, educated men would have known that 'mechanical' also carried a noble classical Greek connotation, deriving as it did from mekhane (contrivance) or mekhanikos (one who contrives) or, in Latin, ingenium and ingeniosus, from which we derive the word 'engineer'. Robert Hooke was also credited with having made hundreds of 'inventions', both from what he recorded in his own notes and from those ascribed to him by his admirers, including Aubrey (1689: p. 166). In an undated manuscript in the Royal Society Library, Hooke (1667) lists 106 of his 'inventions'. Yet here again we must look at the usage of language on scientific matters 350 years ago, which is different in many ways from how we speak today. The Latin word invenire, which is the root from which the English word 'invention' comes, means 'to come upon'. Indeed, it meant not just devising an ingenious piece of mechanism but also scientific discovery itself, for discovery is about 'coming upon' something which one has never previously encountered.

Robert Hooke and John Aubrey and their friends in the early Royal Society therefore saw 'mechanicks', 'invention' and

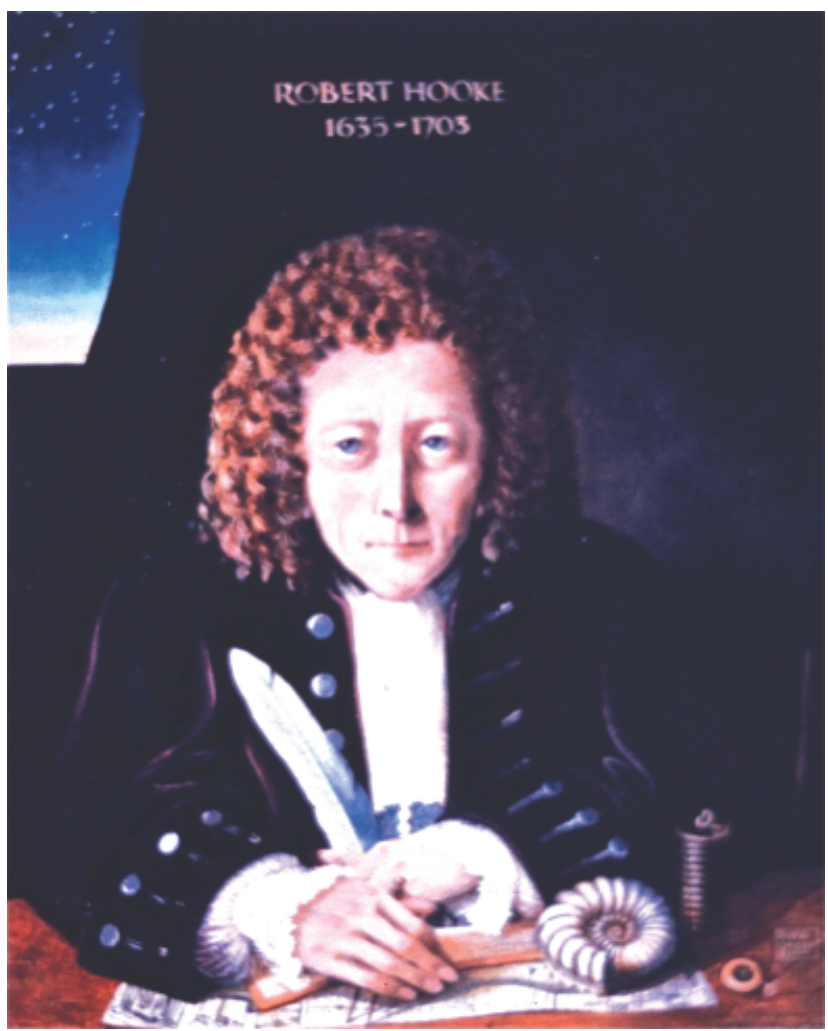

Figure 1. Reconstruction portrait of Robert Hooke by Rita Greer, 2005. Based on detailed written 'pen portraits' by Hooke's friends John Aubrey FRS and Richard Waller FRS. No seventeenth century portrait of Hooke has survived 
'contrivance' as closely related to new and exhilarating natural knowledge, rather than simply the domain of the craftsman at a bench. Indeed, in many ways their guiding star was Sir Francis Bacon's Novum Organon (or 'New Method') (Bacon, 1620) and the posthumously published Sylva Sylvarum (Bacon, 1627) in which Bacon not only spoke in visionary terms about discoveries, contrivances and the transformation of mankind's physical circumstances through science and technology but also listed 'Centuries' or hundreds of areas of nature in which inventions or discoveries had already been made, or where future research was necessary (Bacon, 1627; Spedding et al., 1876). For example, Century 1, no. 33, describes an experiment concerning weight and gravity in mines.

This therefore was the noble tradition in which Aubrey placed Hooke as the 'Greatest Mechanick this day in the World': in a vision of scientia in which discovery, invention and contrivance would elucidate the laws of nature and then go on to use them to improve the human condition. Bacon himself had expressed this visionary process as 'For the Glory of God, and for the Relief of Man's Estate'. We might call it pure and applied scientific research. Either way, it is the root from which engineering science springs.

Robert Hooke holds a pivotal place in the history of the sciences in England in so far as he was working not only within the Baconian tradition but was also, in the early 1650s when he was up at Christ Church, a junior member of a movement that was destined to reshape the world's understanding of nature (Chapman, 2005: pp. 16, 17-20). This was the experimental community out of which the Royal Society was born in 1660 , and to the fellowship of which he would be elected in 1663. Nature was not just to be observed, measured and classified: it was to be taken to pieces by forensic experimental techniques. Its inner processes were to be interpreted mechanically. For example, the heart valves were equated to the controlling 'clacks' or gates of drainage dykes, atoms in chemical reactions became analogous to hooks and eyes in their bonding, the wings of a fly (as viewed through the microscope) were seen as plane surfaces set upon pivots that thickened and thinned the ambient air, sound and light were explained in terms of mechanical vibrations moving through the air or celestial 'aether'; indeed, everything was seen in terms of analogy to clockwork, magnetism, extension, compression, elasticity or reflex. A mechanistic cosmos, in fact. The scientist as engineer!

\section{Hooke's predecessors}

Hooke was not by any means the first Oxonian to be a 'contriver'. There had been, for instance, Roger Bacon, the thirteenth century Franciscan Friar, whose work on optics had really begun experimental science at Oxford. Richard of Wallingford of Gloucester Hall (now Worcester College) had been an applied mathematician and practical mechanician of genius. Both were at Oxford around 1300 and, when he was Abbot of the great Benedictine House of St Albans, Richard's machines had been practical devices of wonder: mathematics writ brass, in fact. Richard's Albion and Rectangulus were genuine ancestors of the computer in so far as they sped up and simplified complex mathematical processes. Yet Richard's masterpiece, and one of the enduring wonders of late medieval Europe, was the complex astronomical clock that he designed and built for his Abbey Church at St Albans. Complete with elliptical gears, no less, it simulated the motion of the heavens by machinery. And in the illuminated annals of the Abbey, Richard is depicted as an ingenious contriver in the noblest sense: standing at a workbench with tools lying around, scribing a brass plate with a pair of dividers, yet wearing not only his black Benedictine habit but also his mitre, and loosely holding his crosier staff, which signified his status as Abbot. Medieval drawings of Richard's astronomical clock mechanism still survive in the Bodleian Library, and have enabled a working replica of part of the gear train to be rebuilt in the late twentieth century, which visitors can see in St Albans Cathedral (the former Abbey). Richard died of leprosy in 1336. (North (2005) provides the most complete single-volume source for Richard's engineering, astronomical and mathematical work.)

Tudor Oxford also inspired several great 'contrivers'. Leonard Digges, who we know was at Oxford University in 1531 (although we do not know which college), wrote extensively on the art of surveying, and his posthumous Pantometria (Digges, 1571) popularised the 'Theodolitus' or theodolite, along with several other surveying instruments and techniques. His son Thomas carried on the tradition of the gentleman-contriver who saw no incongruity between a learned education and a practical talent for designing and fabricating useful devices. Nor did Henry Briggs, John Bainbridge or John Greaves, all of Merton College in the early seventeenth century. Indeed, it was Professor John Greaves who, in his scientific travels in the Levant in 1638, made the first scientifically accurate survey of the Great Pyramid of Giza (Greaves, 1646).

And what an ingenious contriver was the Revd Dr John Wilkins, Warden of Wadham College in the 1650s! Wilkins, an applied mathematician, wrote books about wind-cars, gears, multi-fire crossbows, improvements to cooking utensils and flying machines, among other things (Chapman, 1994; Wilkins, 1638, 1648,1802 ). Wilkins' automatic cooking-spit was, perhaps, the first 'smart' or environmentally responsive mechanism in the history of technology: the hotter the kitchen fire became, the faster an iron aerofoil in the chimney rotated and, via a geared linkage, the quicker the meat turned! He also floated a scientifically 'state of the art' discussion about how one might fly to the moon 'by means of flying chariots'. Wilkins inspired many men, including Seth Ward, John Wallis, the young Sir Christopher Wren and Robert Hooke.

So how, one may ask, does Robert Hooke warrant his special status as the 'Greatest Mechanick' of the age? In one respect, he was the right man, in the right place, at the right time, reaching maturity in a cultural environment in which 'ingenuity' was 
coming to be increasingly defined as an attribute of a cultured gentleman. Indeed, the Marquis of Worcester's popular Century of Inventions Worcester, 1663) (or one hundred ingenious devices) epitomised this movement for clever contrivance in the world beyond the universities and nascent learned societies. I would argue Hooke was much more.

Firstly, he was an experimental scientist of genius. He saw experiments not as philosophical debating points to determine how to proceed in a particular inquiry; rather, he saw experiment as the primary driving force in all natural inquiries. Secondly, he saw experiments as sequential. One experiment led to another, and so on, to embrace all realms of nature; and each experiment stood on the inductive logic of its predecessors. Thirdly, he saw experiment as a mechanical procedure, performed physically, and always meticulously, incorporating measurements whenever possible, or at least, careful observations. Fourthly, Hooke saw the experimental method as encompassing, at least potentially, every branch of natural enquiry, from physics to biology, from geology to the design of machines. Fifthly, he saw it as a public marketplace of science where men of all nations could contribute according to their talents, for there were no secret societies, rituals of entry or especial cognoscenti: the only prerequisite was ingenuity. And sixthly, and very significantly, he saw experiment as instrument based. As will be shown shortly, Hooke perceived the limits of scientific research, at any one time, to be defined by the accuracy of the research tools currently available. Better lenses, more sensitive micrometers and barometers or more accurate clocks were all part of the constant advancement of science.

While it is true that many of these points had been discussed or touched upon by other scientists over the 80 years up to 1660 , Hooke drew them all together as part of a focused method of research. And seventhly, one might say, he actively and restlessly prosecuted this method, on an almost daily basis, from his inspired youthful days when he built flying machines at Westminster School and Oxford, through his years of international glory and fame at the Royal Society in the 1660 s and 1670 s, to his sadly unsuccessful attempts to devise 'an Instrument to take the Horizontal Diameter of the Sun to the tenth part of a [arc] Minute, but discovers not the way' (Waller, 1705: p. xxvi). This last recorded experiment in practical mechanics was attempted in December 1702, within weeks of his death.

\section{Hooke's early life}

Robert Hooke was born on 18 July 1635, at Freshwater, Isle of Wight, where his father, the Revd John Hooke, was resident curate of the parish. His father was a noted scholar, though according to John Aubrey, 'not mathematical'. Thought to be too sickly to be sent away to school, Robert was educated at home, obtaining the rudiments of Latin and Greek from his father, in addition to showing a precocious ability for making sundials, a clock and a model ship, the guns of which actually fired. He also displayed a conspicuous capacity for practical drawing of all kinds. All good instinctive traits, one might say, for becoming the 'Greatest Mechanick' of his age (Waller, 1705: p. ii).

When the Revd Mr Hooke died in October 1648, Robert was somehow conveyed to London, where he ended up - after a brief period in [Sir] Peter Lely's portrait painting studio - at Westminster School. Here, under the formidably learned Head Master, the Revd Dr Richard Busby, Hooke blossomed as a linguist, scholar, inventor, contriver and nascent genius. I think that he got to Westminster courtesy of friends of his late father, such as the Rector of Freshwater, Cardell Goodman. At this period of Civil War upheaval, the Isle of Wight was loyal to the monarchy and the Church of England, and several of its leading figures including Goodman and his predecessor, Samuel Fell - had Westminster School and Christ Church backgrounds. Busby also was a Christ Church (but not Isle of Wight) man, a loyalist Anglican who held on to his headmastership in spite of Puritan purges elsewhere (Chapman, 2005: pp. 7-13; Kent, 2005; Waller, 1705: pp. ii-iv).

Hooke came up to Christ Church, Oxford, from Westminster in 1653. One suspects that he may have been talent spotted at school by John Wilkins, Warden of Wadham and founder of the 'Oxford Philosophical Club' that in 1660 would become the Royal Society. At Oxford, Hooke flourished as a member of Wilkins' circle and, as a 22 year old, was mixing with and learning from some of the leading scientists of the day: Boyle the chemist, Willis the anatomist, Ward the astronomer, Wallis the geometer and cryptologist and the 'universally learned' Dr Wilkins himself. Moving to London in 1662, Hooke became Curator of Experiments and Fellow of the newly founded Royal Society. In 1665, he was appointed Professor of Geometry at Gresham College (Cooper, 2003a: pp. 36-40; Waller, 1705: p. ix).

This was Hooke's 'apprenticeship'. It provided him with the skills, confidence and environment with which to embark upon a course of transformative researches in science and technology. And, following his appointment as Surveyor to the City of London in the aftermath of the Great Fire of 1666, he was on his way to earning architectural fees that would make him a gentleman of very substantial means.

\section{4. 'Artificial organs' and Micrographia, 1665}

As already noted, Hooke's vision of scientific research and progress was intimately bound up with a mechanical view of nature and the need for a progressive instrument technology with which both to gain access to nature's secrets and turn them into useful devices 'for the Relief of Man's Estate' (Figure 2). In the 'Preface' to his immensely influential Micrographia, Hooke discussed the factors that seem to have limited scientific progress over the preceding centuries. He argued that these limitations derived from the very imprecision of our natural senses, especially the sense of vision (Hooke, 1665: 'Preface' (unpaginated), sig. aa (verso)). In particular, he was acutely aware of the ocean of new knowledge that had gushed forth after 1609, when the 


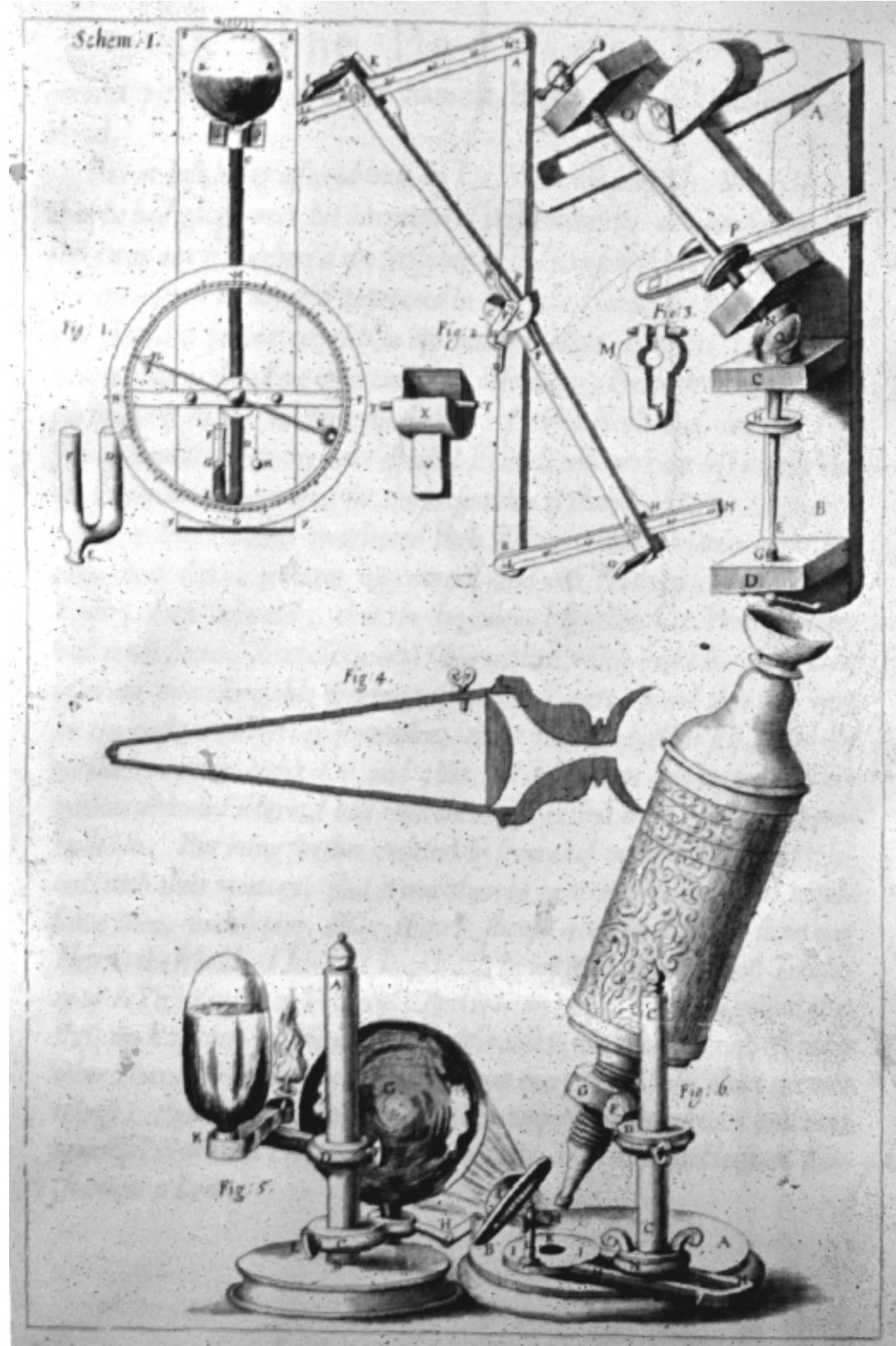

Figure 2. Frontispiece of Micrographia (Hooke, 1665). From top left: Hooke's 'wheel barometer'; instrument for measuring refractive indices of fluids; lens grinding and polishing lathe; microscope and illumination system

newly invented telescope had revealed the planetary and stellar universe to be a very different place to that visible to the naked eye. Galileo's first modest telescopes had disclosed hitherto unimagined wonders, although the much larger and more powerful ones available by 1665 made the discoveries of 1610 pale into insignificance. And who knew what else awaited future discoverers as telescopes became yet more powerful?
Likewise, the microscope, which was the real subject of Micrographia, had displayed another hitherto unimagined universe of the minute: a universe in which one could study the anatomy of 'A Flea, a Mite, [or] a Gnat' in as much detail as if it were 'A Horse, an Elephant, or a Lyon' (Hooke, 1665: 'Preface', sig. gg (verso)). A universe, moreover, in which the most delicate of human manufactures, such as the blade of a finely honed razor or 
Engineering and Computational Mechanics Volume 164 Issue EM4
Dr Robert Hooke and the origins of engineering science

Chapman a piece of gossamer silk, looked rough and coarse whereas the works of God - plant structures, crystals or fleas - became ever more wonderful in their divine contrivance each time one increased the magnification.

No one had ever looked at natural objects in this way before, nor drawn attention to the inner wonder of the specimens under study. Lenses, micrometers, barometers and all manner of experimental apparatus were described as 'Artificial organs' that strengthened natural ones (Hooke, 1665: 'Preface', sig. aa (recto)). (Bennett (2003) gives a modern assessment of Hooke's instruments.)

Nor was it simply a matter of seeing better. What Hooke was talking about in Micrographia was an entire revolution in perception itself. The better optics were only part of it, for Hooke's instincts as an engineer and a physicist drove him to see these newly revealed realms as dynamic structures - as natural machines within a greater machine of nature. Take, for example, Observations 38 and 42 in Micrographia of a common blue fly (Hooke, 1665: pp. 172-174, 182-185) (Figure 3). Hooke's

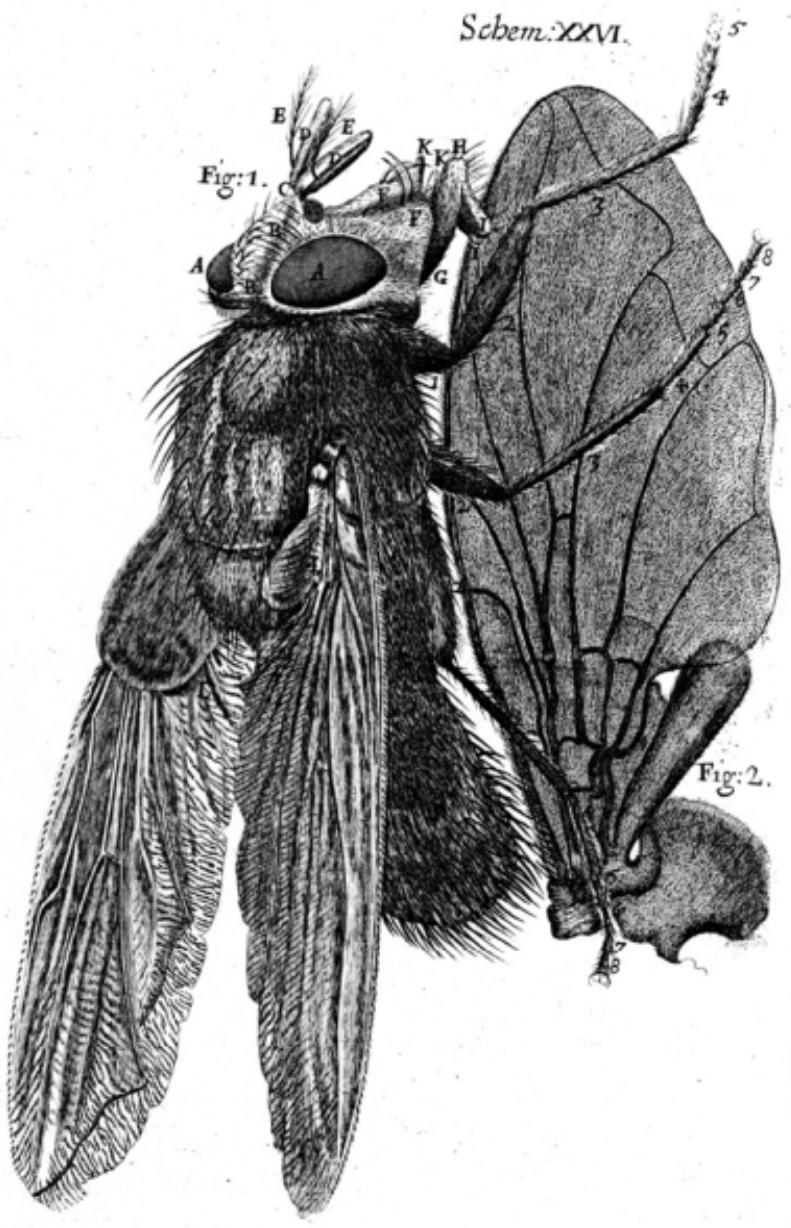

Figure 3. Blue fly: an insect as a study in aeronautical engineering (Hooke, 1665: Scheme 26) account of the fly, however, (like his other insect studies) is not about entomology so much as aeronautical engineering. He looks at the fly's body as though it were the fuselage of a flying machine - which it was, in his eyes - and he expresses wonder at its contrivance. The wings were hard, shiny planes controlled by immensely powerful muscles, while the 'pendulums' that hung down beneath (which we might think of as part of the fly's guidance system) he thought were rapidly moving valves that may have been part of the insect's respiratory system. He describes the configuration of the legs, the suction feet and the optical beauty of its two vast eyes, which under the microscope resembled a 'Lattice, drill'd through with an abundance of small holes' but which, when the sunlight was positioned correctly, resembled a 'Surface cover'd with Pyramids; in another, with Cones' (Hooke, 1665: 'Preface', sig. ff (verso)).

So the fly was an elaborate structure of curved surfaces, powerful muscles and pivoted wings: wonderfully jointed, with air-valvecontrol mechanisms and amazing multi-faceted eyes. Yet, Hooke asked, why did flies buzz when they flew, whereas butterflies and moths were silent? Silent flyers had wings that were covered with a powdery down, which he saw as trapping air, in the same way that a modern lifejacket does. This meant that these insects needed to expend far less energy when they flew, although their flight was relatively slow. Buzzing insects such as flies and bees, however, had hard, glassy, stretched membrane wings that could not trap any air, and could only sustain flight if moved with incredible rapidity so as to create a succession of denser and more rarefied pockets of air that kept them airborne. This is why the fly was found to be such a spectacularly engineered creature.

In his concern for quantification and design, Hooke then went on to wonder how many times per minute a fly would beat its wings. And here we encounter a splendid example of inspired lateral thinking in acoustics and engineering. First of all, Hooke somehow persuaded a fly to land, feet down, on a spot of glue on the end of a quill, so that it could not escape. Then, tilting the quill, he heard the pitch of the buzz of the fly's wings change as the creature attempted to fly forwards or upwards. Having a good musical ear, he was able to identify the musical pitch of the buzz and then tune the string of a musical instrument to the same pitch. From the vibrating length necessary to produce the note in a wire or string under tension, and presumably working from the reciprocals of geometrical chords, he concluded that a fly beat its wings 'many hundreds, if not some thousands of vibracions in a second minute of time' (Hooke, 1665: p. 173). It is possible that by 8 August 1666, some 20 months after Micrographia was published, Hooke had refined this figure: for on that day, Samuel Pepys recorded a conversation with him on the subject of insect flight, musical sound and vibration, though the unmathematical Pepys found it 'a little too much refined', albeit 'mighty fine' (see Latham (1986: p. 649) for the extract from Pepys' diary).

I would suggest that Hooke's published studies on the flight of insects presented in Micrographia laid the foundations of aero- 
nautical engineering (Leonardo da Vinci's work on birds would not be published or widely known before the nineteenth century) and were entirely original. It was not until Cayley and Stringfellow began to experiment with scientifically devised flying machines in the late Georgian and early Victorian period that Hooke's work would be taken further (Gibbs-Smith, 1962).

All of this stemmed from an enhanced capacity to see natural structures by means of the 'artificial organs' supplied by new optical and mechanical devices. The microscope, in particular, confirmed Hooke's already established propensity to see nature as a vast realm of interlocking integrated mechanisms. Time and time again in Micrographia, as he beheld one hitherto-unimagined natural structure after another (flying creatures, the structure of cork, the multi-planar layering of mica, the stings of nettles, the cellular and nutrition-conveying conduits of plants, the flexibility of feathers and many other things besides), one sees Robert Hooke responding with the instincts of an engineer (see Hooke, 1665: pp. 112-116 (cork), 47-51 ff (mica ('Muscovy Glass')), 142-145 (nettles), 114 (cellular conduits), 165-167 (feathers)). How do such structures work so perfectly, he asked, and what can we learn from them when fabricating our far less perfect mekhanai?

\section{Motion and elasticity}

Robert Hooke's enduring model for nature was that of the machine, yet two particular aspects of this machine haunted his thinking from his youth onwards. He wanted to understand the nature of motion and of elasticity. While there was neither a word for, nor a precise concept of, what we now call energy in the seventeenth century, Hooke constantly thrashed around for some designation for a kind of power in nature. Words such as force, pondus (weight), pressure, impact, tension and so on occur in his writings, for a defining characteristic of the machine of nature was motion. Hooke's cosmos - on every level from atoms to planets - was permeated by motion and he saw the business of physics as the tracing of this elusive force through all of the natural machines that the 'experimental philosopher' studied.

The source of motion was seen as divine, though once the Almighty had created the phenomenon, the philosopher could study its effects in all manner of natural machines, from orbiting planets to a fly's wings. While motion itself could not be seen, its effects were conspicuous and measurable, be it witnessed in a hammer striking an anvil or in its transmission through a train of gears. As a 'mechanical philosopher', Hooke saw motion as causing all kinds of change as atoms impacted upon each other. Indeed, even decomposition within organic bodies was attributed to tiny internal motions that were different from the motions that took place in a living body (Waller, 1705: pp. 315-316; see also 'motion' in the index).

In his astonishingly original and imaginatively conducted researches into flame and combustion (see Boyle (1660) and Hooke (1665: pp. 100-106)), Hooke concluded that fire occurred only when heated 'sulpherous' or combustible particles made contact with excited air, so that the air became a 'menstruum' or solvent that devoured the combustive matter. Yet it was not just any kind of air that was necessary: it was that particular component present in any volume of common air that seemed to resemble the fierce combustive 'menstruum' emitted by red-hot saltpetre (potassium nitrate $\left(\mathrm{KNO}_{3}\right)$ ), for when this nitrous volume of air had been consumed, burning ceased, in spite of a seeming abundance of air remaining in the vessel. But what was this nitre-related property, a relatively small volume of which was present in common air and which facilitated both combustion and respiration? We might leap to the conclusion that Hooke had identified oxygen, but this would not be correct: no seventeenth century researcher had any real concept of a chemically specific gas. Instead, as a mechanical philosopher, Hooke - like his mentor and friend the Hon. Robert Boyle before him and his younger contemporary and protégé Dr John Mayow - thought of this combustive, or dissolving, agent more as a compressional state of chemically homogeneous yet mechanically elastic common air: when air was in the correct compressional state and it encountered 'sulpherous' matter, then both flame and breathing were possible. Other compressional states could lead to the air exploding in coalmines or producing the flame and life-suppressing 'damps' of metal mines. Hooke's and Boyle's experiments with Boyle's prototype airpump on the High Street, Oxford, around 1660, seemed to confirm the compression and attenuation properties of air.

Yet at the heart of all this thinking were motion and mechanism as particles impacted upon each other. Exactly the same intellectual principles ran through Hooke's truly brilliant researches into flame, which he presented to the Royal Society in 1677 as part of his attempt to improve the efficiency of lamps and in which he traced the motion of 'sulpherous' particles in the oil, up the wick and to combustion in the flame (see Hooke $(1671,1677)$ and Chapman (2005: ch. 2)). And not only did the oil burn in the flame, it seemed to do so in different temperature or luminosity zones. At the heart of the flame was a blue cone, which Hooke discovered contained excited sooty particles that could not actually combust because they lacked access to ambient air. However, when he inserted one end of a small metal pipe into the cone to draw off the particles, he could use the released material to start a quite independent flame at the other end. Yet all of this stopped if the oil ceased to move and the ambient air's compression did not produce 'aerial nitre'. Flame, it seemed, just like the action of a fly's wing, was an environmentally responsive natural mechanism.

Central to Hooke's lifelong study of motion was his fascination with elasticity and the elastic responses of a wide variety of natural and manmade substances such as air, steel, muscle and various fibres. Why did certain substances seem to absorb external motions, only to release them later? His classic 'Law of Spring' (see Hooke (1676: Appendix, item three on the list of ten 'inventions' to try) and Hooke (1678: pp. 1-5)) is probably the best-known of all Hooke's 'inventions': Ut Tensio, Sic Vis ('the 
force is equal to the tension') or, in its original 1678 formulation, Ut Pondus, Sic Tensio ('the tension is equal to the weight'). Either way, it shows, within the limitations of the physics concepts and language of the day, how Hooke was trying to grapple with the ideas of energy, compression and motion, and was laying down a foundation for a science of materials.

Nowadays, however, with three centuries of further research into the physics and engineering of elasticity behind us, especially from the nineteenth century onwards, one might modify Hooke's original formulation along the lines of 'as the tension, so the force' as an expression of linear elasticity. On the other hand, we have to bear in mind that, in 1678, Hooke was not only at the technical and experimental cutting edge as far as physical research was concerned, but was also at the edge conceptually and linguistically. For, as noted earlier, seventeenth century Europe had no coherent concept of what we now call 'energy'; in Latin words such as pondus (weight), tensio (tension), vis (force), etc., Hooke was struggling to find a precise formulation for a property of nature that he was becoming increasingly aware of as something more than just a hunch, but which he could not adequately express either in words or mathematical symbols. While humanity had been utilising 'springiness' on a daily basis since time immemorial, for bows and arrows and the like, no one before Hooke had attempted to understand elasticity 'philosophically'.

Of course, Hooke's work on 'Spring' was conducted in part as a component of his researches into horological engineering, of which more will be said later, but his wrestling with the principles of elasticity was connected to his wider vision: namely, how did the great machine of nature work and how could one learn from it to 'relieve Man's Estate'?

Hooke hoped that he might contrive some sort of 'artificial muscule' (muscle) that would make this possible. Indeed, as detailed in his diary entry for 11 February 1675 (Robinson and Adams, 1968), he told the Royal Society that he had 'a way of making artificial muscule to command the strength of 20 men. [And] Told my way of flying by vanes [wings] tryd at Wadham'. It is unclear from his diary entry for this date, however, whether the 'artificial muscule' was a contemporary line of research in 1675 , or whether it went back 20 years to when he and Dr Wilkins were contriving flying machines in Wadham College in the 1650s. One wonders what his artificial muscles might have been made of in this pre-rubber age, but from remarks found elsewhere it is likely that he and Wilkins were storing and releasing their 'force' in steel springs.

Sadly, neither Wilkins nor Hooke ever did soar aloft in a springand wing-powered 'flying chariot' though their painstaking efforts, based on the best physical and technical knowledge of the day, could perhaps qualify Wadham College, along with Kitty Hawk, North Carolina, 250 years later, as one of the ancestral birthplaces of aeronautical engineering.
Natural muscle fibre also fascinated Hooke. By 1675, he was engaged in a series of microscopic examinations of animal and bird muscle material, which suggests that when he spoke of his 'artificial muscule' to the Royal Society on 11 February 1675 he was discussing ongoing research. Between 1675 and 1678, he came to see natural muscle as consisting of chains of connected round structures 'which seemed like a necklace of pearl' (Birch, 1756: entry 25 April 1678; Waller, 1705, p. xx). Hooke pondered whether some kind of 'very agile matter' passed along the 'necklace' and inflated each 'pearl', causing it to expand when the muscle was brought into operation? Indeed, this fits in nicely with Hooke's wider idea of pneumatic or hydrostatic action in the body. It accords with William Harvey's idea of the heart and vascular system resembling a series of canals, lock gates and sluices, and Hooke's own anatomy teacher Thomas Willis' idea, as well as that of René Descartes, of the brain as supplying pressurised 'animal spirits' (cerebro-spinal fluid) through the nerves to activate the senses. For were not human and animal bodies divinely contrived 'engines' that could be explored, and even explained, by human ingenuity? It is indeed likely that Thomas Willis of Christ Church, Oxford, taught Hooke anatomy and that his Cerebri Anatome (Willis, 1664) had a profound influence on Hooke.

But motion, elasticity and 'vibracion' lay more deeply embedded in Hooke's scientific psyche than perhaps any other body of ideas: the waveform, shock or impulse were foundational principles to him, as he envisaged the whole cosmos as filled with an 'aether' through which 'force' passed. And, depending somehow on the amplitude of the 'vibracion', the shock manifested itself as light, gravity, magnetism or sound, in something resembling a grand unified theory (for more detail see Chapman (2005: pp. 43-44, 175)). Light, for example, was an impulse coming from the heavens. When one side of the shock wave impinged upon the retina it created an impression of blueness and when the other impinged it created the sensation of redness. From these findings, based as they were on the passage of rays of sunlight at varying degrees of tilt through long conical flasks of water, Hooke drew the conclusion that redness and blueness were innate mechanical properties of nature and that greens, yellows and oranges occurred when the rest of the wave snaked its way through the eye's membrane (see Hooke (1665: Obs. IX and X, pp. 46-67, 67-77) and Waller (1705: pp. 120-121, 4 June 1681)). This two-primarycolour model of vibrative light was later to be disproved and built upon by Sir Isaac Newton but, as the young and still modest Newton told the Royal Society in February 1672, it had been a problem in Hooke's 'inflexion' theory of light and colours, and in particular a paradox displayed in Hooke's experiment using hollow glass prisms filled with red and blue liquids, that had stimulated him to investigate the spectrum (Newton, 1671).

While Newton replaced Hooke's idea of vibration and waveform with an equally mechanical one of 'corpuscles' travelling at different velocities, Thomas Young reintroduced Hooke's waveform back into science in the early nineteenth century, whereafter 
it proceeded to become one of the most universal explanatory models in physics.

Having seen Hooke's ideas about mechanism and nature, let us now examine some of the actual machines he pioneered.

\section{Hooke and mechanical invention}

In the short autobiography that Hooke composed and which was published in 1705, along with what his friends John Aubrey and Richard Waller set on record, we can trace a lineage of hands-on invention and contrivance that extended back to his childhood in Freshwater. As a Westminster schoolboy he invented 'thirty severall wayes of Flying' (Aubrey, 1689: p. 165) and as an Oxford undergraduate he not only conducted experiments with pendulums and allegedly designed a spring balance for watches (Waller, 1705: pp. iv-v) but also assisted Dr Wilkins in his attempt to build a flying chariot (Chapman, 1991; Hooke, 1675); one such machine 'rais'd and sustain'd itself in the Air' (Waller, 1705: p. iv). It is clear that not only philosophical but also practical contrivance was part of Hooke's intellectual make-up.

Of the myriad of devices to which Hooke devoted his attention, three deserve special mention because of what they led on to. The first of these was the airpump or vacuum pump that he designed for Boyle in 1658/59 while working as Boyle's assistant at Deep Hall on Oxford's High Street. In the wake of Evangelista Torricelli's discovery of an airless space above the water or mercury levels in sealed tubes during his experiments with fluid dynamics in 1644, several people had attempted to make a sealed, efficient vacuum pump, most notably Otto von Guericke of Magdeburg. Such a pump was devised so that relatively large enclosed volumes - such as barrels - could be evacuated and experimenters could investigate the chemical, physical and mechanical properties of the vacuum. Robert Boyle wanted a pump and, after an earlier one built for him by the pumping engineer Ralph Greatorex had proved inadequate for his purposes, he approached Hooke (Waller, 1705: pp. iii-iv) (Figure 4).

In 1658, Hooke (then aged 23) was living in Oxford, on the academic books of Christ Church, his college, and probably earning his living as what we would now call a short-term contract worker (Kent, 2005: pp. 46-49; Waller, 1705: p. iii). He had already established a brilliant reputation for himself as Dr Wilkins' ingenious protégé. He had been Willis' chemical and probably anatomical assistant and, by 1658 , had been headhunted by Boyle, probably because of his proven capacity as a designer of 'artificial organs' or instruments.

It is not clear who - Boyle himself, Greatorex or Hooke contributed what to Boyle's epochal airpump, but the eventual machine was to become in many ways a prototype. At the heart of the pump was the heavy brass piston and cylinder. By means of strategically placed manually operated valves working in conjunction with the piston rackwork, air was sucked out of a large (about 15 in $(38.1 \mathrm{~cm})$ diameter) glass vessel, or 'receiver',

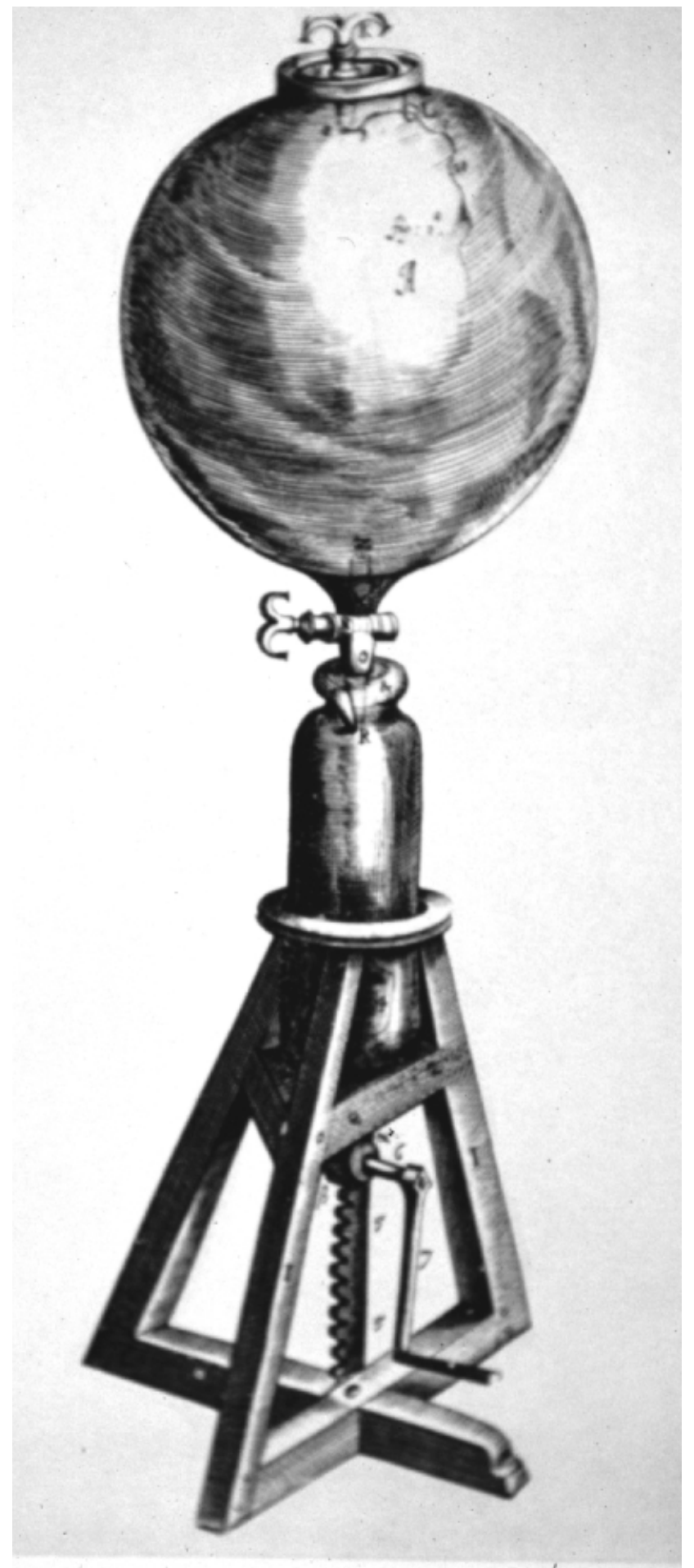

Figure 4. Hooke's vacuum airpump (about $3 \mathrm{ft}(\approx 90 \mathrm{~cm})$ high), designed for Boyle. Maker unknown, but perhaps Ralph Greatorex

into which a carefully designed experiment had been placed prior to evacuation. Unlike von Guericke's evacuation barrels or iron spheres, Hooke's airpump rendered all aspects of the experiment visible through the glass. It took about $3 \mathrm{~min}$ of pumping to 
Engineering and Computational Mechanics Volume 164 Issue EM4
Dr Robert Hooke and the origins of

engineering science

Chapman achieve a tolerably good (though by no means perfect) vacuum; because of the relatively poor lathing techniques of the day, the valves squeaked as they let air back in, and Boyle and Hooke resorted to pouring 'Sallad Oyl' into the valves in the hope of clogging them up sufficiently to complete an experiment (Boyle, 1660: p. 8).

But, who actually made this airpump? It was certainly not Hooke, though he may have used his proven bench skills to do the finishing and fitting. Quite simply, to build such an airpump in 1658 , one needed industrial resources. My suspicion is that a gunsmith was employed to cast and drill out the 3 in $(\approx 7.6 \mathrm{~cm})$ bore of the cylinder, which had the dimensions of a small cannon. At that time, gunsmiths or cannon founders were the only craftsmen around who could undertake heavy precision work of this kind, though one assumes that such skilled gun-casters were not hard to find at the end of the Civil Wars period. On the other hand, Hooke could well have turned the piston head and smaller valve holes and plugs, for Aubrey tells us that as a Westminster schoolboy Hooke had become proficient in the art of lathe turning - perhaps as a diversion from the Latin and Greek that he also mastered at school! (Aubrey, 1689: p. 165; Waller, 1705: p. iii). The great glass receiver seems to have been a very special commission, probably from a Dutch glasshouse. Boyle (1660) and Maddison (1969: pp. 92-98, 227-233) give detailed accounts of the airpump.

In the 1920s the meticulous illustrations and descriptions of this airpump were used to build at least two full-scale replicas. In 2002, Michael Wright and I tried out one replica (from the collection of the Science Museum, London) for a BBC television programme on the life and achievements of Robert Hooke, broadcast in early March 2003 to commemorate the 300th anniversary of Hooke's death. (The other replica airpump is held at the Museum of the History of Science in Oxford.) Although the 80-year-old leather seals had shrunk (but improved after liberal dosings with modern machine oil), thus preventing us from getting anything more than a very poor and transient vacuum, we easily mastered the knack of operating the piston and valves in the correct sequence and proved to ourselves that this really was an ingenious machine, albeit at the very cutting edge of large-scale precision engineering capacity for its day.

The course of experiments that Boyle and Hooke went on to perform with this Machina Boyleana and its improved and more powerful successor of 1667 quite simply changed the way in which scientists saw nature as having been put together. They showed that air was not a uniform element of nature but a curious substance that could be compressed or attenuated and which displayed a variety of 'physico-chemical' properties in the process. In addition to its role in combustion, air was demonstrated as reacting with pulmonary blood in respiration; light could pass through a vacuum, whereas sound could not; and pieces of red-hot iron suspended in vacuo could somehow radiate a 'force' that warmed the glass of the receiver while having no apparent contact with it (Boyle, 1660: pp. 48-50; Boyle, 1670a, $1670 \mathrm{~b}$ ). What is more, gunpowder could be ignited in vacuo, but instead of exploding it merely fizzled. Did this curious property of gunpowder derive from its saltpetre $\left(\mathrm{KNO}_{3}\right)$ active ingredient, which, as indicated in Section 5, was known to contain a powerful fire-inducing solvent?

It was hardly surprising that the airpump was seen as one of the defining pieces of scientific research technology of the seventeenth century (see Shapin and Schaffer (1985) for a discussion of the impact of the airpump on wider philosophical issues). And it was Hooke who had supervised construction of the parent machine, probably at Deep Hall, High Street, Oxford.

The same Torricellian experiments in fluid mechanics and pressure that led to the airpump also made possible the barometer. Although Hooke had no claim to the basic design of the mercury barometer as such, he was part of that circle of Oxford experimentalists, most notably Boyle and Sir Christopher Wren, who realised in 1659 that changes in the mercury level came about not because of a Cartesian vortex pressure from the orbiting moon but from approaching and receding storms in the atmosphere (Chapman, 2005: p. 278; Derham, 1726: p. 2; Waller, 1705: pp. vii-viii). By the 1660s, moreover, the barometer was coming to be used in conjunction with early thermometers and hygrometers (or hygroscopes), as Robert Hooke's proposed 'History [or Register] of the Weather' for the Royal Society in 1667 now envisaged meteorological phenomena as related to measurable physical quantities of heat, humidity and barometric pressure (for drawings of Hooke's 'Wheel Barometer', windgauge, and 'Hygroscope' (hygrometer), see Sprat (1667: p. 173). Observation 27 in Micrographia describes Hooke's suggestions for hygrometric instruments, using moisture-sensitive fibres to exert pressure on a pointer moving around a calibrated dial (Hooke, 1665: pp. 147-152).

It was in his efforts to make the mercury barometer more precise that we see once again Hooke's astonishing genius for practical mechanism in action. Early mercury barometers, consisting as they did of a simple straight tube of glass, were often difficult to read with much precision. Hooke realised that if the weather was ever to be understood scientifically, it was necessary to monitor very small as well as big changes. To this end, in the early to mid 1660s, Hooke devised his 'Wheel Barometer'. In his design, mercury was contained in the usual long glass tube, the bottom of which, however, was bent into a $U$ shape. The upper straight end of the tube was closed, having been blown into a glass ball that contained a vacuum space, but the lower end, where the $U$ bent upwards, was left open. Air pressure acted downwards on the open upturned bottom of the tube and upon this surface of mercury Hooke placed a float: a counter-poised metal ball upon a thread. The thread, in turn, was wrapped around a turned cylinder set upon a delicate bearing and carrying a pointer that moved inside a calibrated circle: the 'wheel' of the barometer. Hooke was rightly proud of this 'baroscope' or barometer, which repre- 
sents a very early example of applied precision engineering thinking directed towards making a newly discovered scientific principle more readily evident to the observer. He discusses it in Hooke (1665: sigs. c (verso) and cc) and Hooke (1666, 1686). The intention was to magnify the smallest change in mercury level and make it evident by means of the pointer and wheel.

If the wheel barometer is one indication of Hooke's genius as an inventor of precision mechanisms, the 'Weather Clock' on which he and Sir Christopher Wren were working at various times during the 1660 s and 1670 s displays an even greater piece of engineering science insight. The weather clock brought together several key elements of how precision instrumentation was developing by the 1670 s. The aim was to build standard meteorological recording instruments to collect data on humidity, temperature, rainfall and barometric pressure. Once a large and detailed body of data had been amassed, it was hoped that the physical causes of the weather could be elucidated and used to make predictions. However, the manual collection of such data was tedious: in order to obtain a realistic body of data for analysis, each single instrument would have had to be read every 15 or $30 \mathrm{~min}$, day and night. And then it occurred to Hooke, Wren, or both: could not a clock-powered apparatus be devised whereby all of these quantities could be recorded automatically?

By December 1678, Hooke was confidently telling the Royal Society that within 6 weeks a device would be shown that would automatically record no less than eight different aspects of the weather on a continuous basis. Sadly, this visionary piece of precision engineering proved beyond the skill of manufacture of London's finest craftsmen and it came to nothing concrete (Birch, 1756: p. 445, 5 December 1678). After Hooke's death, however, his horological 'executor', the Revd Dr William Derham FRS, described a weather clock design found among Hooke's papers that was similar to the instrument published in a drawing. Derham (1726: p. 41) tells us that in this design an 8-day pendulum clock advanced a paper-covered cylinder and a flat recording plate, while at each 15 min interval a punch device stamped out the current temperature and barometric pressure onto the slowly moving surfaces (Figure 5). I believe this to be the first proposed use of an automatic pen recorder.

The imagination and technological foresight displayed in the weather clock were truly amazing, for when Hooke and Wren were born, within 3 years of each other in the 1630 s, the weather was largely a mystery. By their 'postgraduate' years it had been discovered - within their own circle of experimentalist friends in Oxford - to be dependent on barometric pressure. By the late 1660 s, not only had instruments been devised to record each of its key ingredients of pressure, temperature and humidity manually, but precision engineering mechanisms had also been designed to record each of them fully automatically and present them to the scientist as a trace mark on a piece of graduated paper. Only the limited mechanical technology of the age held

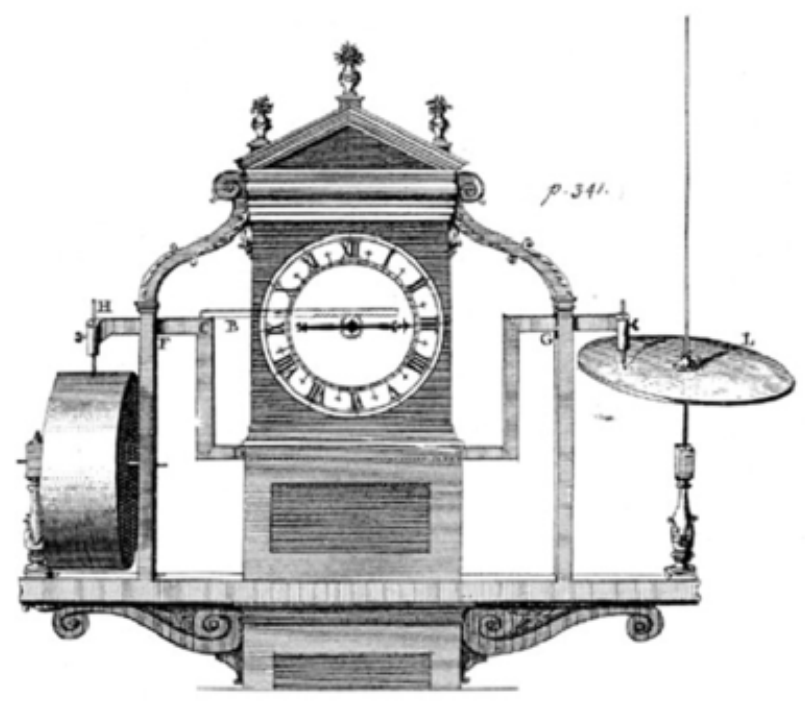

Figure 5. 'Weather Clock'. Design by [Sir] Christopher Wren submitted to the Royal Society on 9 December 1663, and to which Hooke suggested additional functions and improvements. This machine seems to have stimulated Hooke's interest in selfrecording instruments, in particular the 'Weather Clock' registering eight functions that he was trying to perfect up to 1678. This engraving, however, remains the only known picture of such a clock (Birch, 1756: Plate III)

back the full realisation of their stupendous and visionary piece of engineering science.

Indeed, it would not be until the 1840 s that the dream of a continuous automatic meteorological (and, by then, also magnetic) record would come to fruition when Mr Charles Brooke's ingenious use of newly invented photographic paper, reflected light beams and precision clockwork motors moving the recording surfaces was adopted by the Greenwich Royal Observatory Meteorological Department. These instruments were discussed (unsigned) by Frederick Knight Hunt in 'Greenwich Weather Wisdom' (Dickens, 1850). A more detailed account of the Royal Observatory and its instruments was published in the Edinburgh Review (1850).

The branch of mechanical invention most obviously associated with Robert Hooke, however, is horology. Although the use of falling weight, gear train and escapement had been fully familiar to Richard of Wallingford in 1330, and clockwork was used to actuate automata or simulate planetary motion in medieval times, the actual time-keeping accuracy of such clocks had been poor. This was because pre-1658 escapements were simple recoil mechanisms that ran at one speed when fully wound, and then slowed down thereafter. The breakthrough had come about in 1658, when Christiaan Huygens in Holland adapted a mechanism whereby a Galilean pendulum - with its physically equal, or isochronal, swings - could be connected to a gear train 
Engineering and Computational Mechanics Volume 164 Issue EM4
Dr Robert Hooke and the origins of

engineering science

Chapman
(Huygens, 1658). All of a sudden, it became possible to use the isochronal physics of the pendulum to make clocks keep time to almost as many seconds per day as the old escapements had kept to minutes (Birch, 1756: pp. 4-5; Waller, 1705: pp. vi-vii). It was also perhaps the first time that engineering science had benefited from a recently discovered principle in pure physics. Huygens' clock, which had a sudden and enduring impact on European physics and astronomy instrumentation, was made by the master clockmaker Solomon Coster. (For clock accuracy after the pendulum, see Pledge (1966: p. 70) and for a fuller discussion of Hooke's horology, see Chapman (2005: pp. 174-182, $302-$ 305).)

Robert Hooke saw Huygens-type clocks, either in London or in Oxford, very soon after they reached England. They caught his imagination in two ways. Firstly, he saw them as potential sea chronometers if they could be mounted or suspended in the right way in a ship's cabin so that the vessel's rolling did not make the gravity-dependent pendulums miss their beats. Secondly, he began to explore how the isochronal action of the pendulum could be liberated from the vertical, so as to make it reliable when moved about or held in any position. In this respect, we encounter one of the numerous examples of Hooke's fascination with elasticity: if the 'force' necessary to tension a spring was directly proportional to the energy released from it, was not spring action itself a manifestation of isochronalism? This was to lead to attempts to devise a successful 'pendulum watch' (or portable timekeeper) possessing, it was hoped, the same accuracy as one of the new Huygens pendulum clocks but using a spring rather than an actual pendulum to control the escapement.

Of course, mainsprings had been used to provide the motive power for portable clocks and watches since the late fifteenth century and, in 1660, watches were common across Europe. It is true that most watches sold over the counter in London in 1630 would have been very expensive pieces imported from the continent, though by then a small number of English and Scottish craftsmen were making them (see, for example, Britten (1986: pp. 37-68) and Thompson (2007)). Yet all of these watches contained variations on the recoil-based 'verge and foliot' escapements, which were miniaturised versions of the escapements used in church clocks. What Robert Hooke aspired to do - as did Christiaan Huygens - was to devise a viable mechanism whereby the isochronal reflex action of a fine 'tender' spring could control the rotary action of the watch's balance. In this way, the driving force of the mainspring would be released in exact measured bursts, and the watch would hopefully keep precise astronomical time.

Rather infuriatingly from the historian's point of view, no documents survive that can firmly pin down what Hooke was doing in detail with balance springs before the early months of 1675 , by which time he had shown a balance spring watch, made by Thomas Tompion, to King Charles II (see Hooke's diary entries for 7 April 1675, 17 and 18 May 1675, 25 May 1675
(Robinson and Adams, 1968) and Derham (1714: p. 103)). But by 1675 , Hooke was defending his priority against a similar mechanism being demonstrated by Huygens. Who invented what first does not really involve us here and it is easy to suspect that both Hooke and Huygens, both of whom were very big players in the world of contemporary science-based invention, came up with a watch balance incorporating similar principles at the same time. In 1675 , Hooke was claiming that he had been devising workable spring balances for perhaps 15 or 16 years, which would put them well into his Oxford period before the Royal Society was formally founded (Hooke, 1676: pp. 26-30; Waller, 1705: pp. iv-v). Sometime after the restoration of the monarchy in May 1660, he claims that he was invited by a group of eminent gentlemen within his circle to declare the detailed working principles of his invention for a handsome public reward, but the shrewd Hooke was not happy with the legal details and revealed nothing. Likewise, he discussed the general, but not the detailed, features of his spring balance escapement in his Cutlerian lecture before the Royal Society in 1664 (Hooke, 1676: p. 29) (Figure 6).

Yet exactly how was Hooke using his energy principle of spring to control a watch balance? Was the spring a spiral, a curve, a zigzag, or even a long, straight, very flexible 'tender' piece of steel that whipped side to side just like a pendulum to engage with the balance cocks in the escapement? From what survives in manuscripts and in oblique remarks, he probably tried them all from the late 1650 s onwards; however, by 1675 , Hooke - like Huygens - was using a curved or spiral balance spring (Wright, 1989). It was hoped that when the long-lost Hooke manuscript dealing with the early Royal Society meetings first came to light in 2005 , crucial new evidence would emerge. I had the privilege of being invited to examine the manuscript in the vaults of Bonhams auctioneers, and spent 5 hours going through the volume. The manuscript - now safely preserved in the Royal Society library and fully available in transcription on the internet - cast many valuable shafts of light on Robert Hooke and his scientific activities, but failed to provide clinching details of his watch escapement.

Hooke's watch escapement and his priority dispute with Huygens became something of a cause célèbre in the history of technology. But what really matters, beyond priorities, is the actual significance of the invention. For it proved to be yet another significator of how rapidly science-based technology was moving by the 1670s: how new discoveries in physics - pertaining to the isochronalism of both pendulums and springs - were applied to transform an already existing invention, the 'common watch'. While Hooke's balance mechanism did not turn out to be as mechanically reliable as he had hoped, it nonetheless laid the foundations upon which other inventors and precision engineers would build. By 1720, for instance, George Graham FRS, physicist, clockmaker and precision engineer par excellence of the next generation, had turned Hooke's spring balance into a standard reliable piece of widely available commercial technology (Chapman, 1990a, 1996). And learning from and encouraged by 


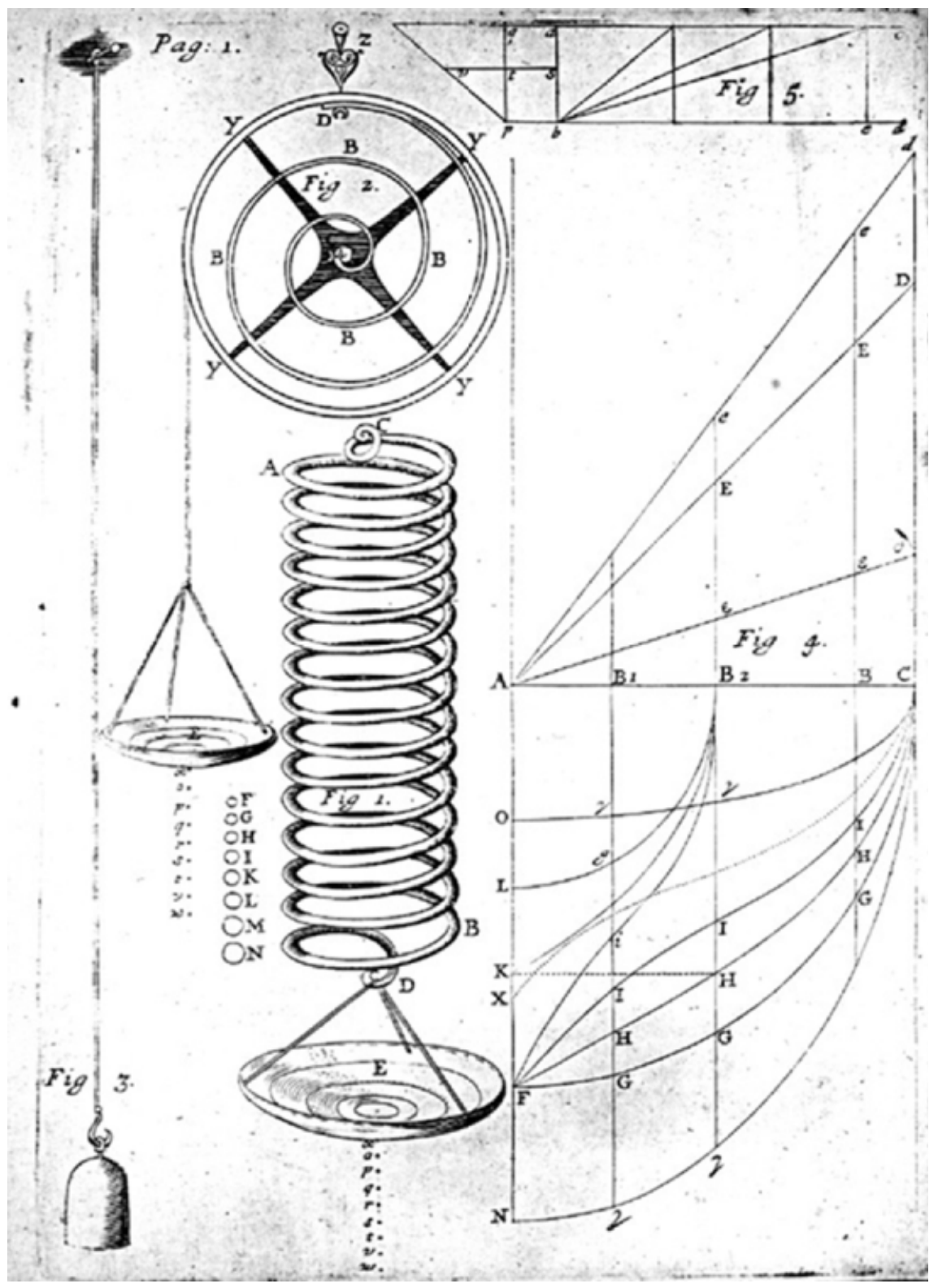

Figure 6. Studies in spring, tension and the mechanics of 'force' (energy) (Hooke, 1678)

Graham, John Harrison produced his first astonishingly accurate marine chronometer in 1735: a machine, indeed, that contained many Hooke-inspired operational parts (e.g. balance springs, precision-engineered escapement and mechanisms to compensate for the pitch and roll of the ship) and drew upon Hooke's ideas of elasticity, flux and reflux. Indeed, Harrison's own researches into the physics and design of complex engineering structures won him the Royal Society's prestigious Copley Medal in 1749: probably the first major academic award to be given to an engineering scientist.

The three case studies examined above - the airpump, the barometer and the spring balance watch - all drew their fundamental inspiration from Hooke's abiding concern with motion and elasticity, and his capacity to transform their physical principles into useful scientific machines. But Hooke's relentless 'ingenuity' also drove him to a lifelong concern with improving machine tools.

\section{Machine tools and practical contrivances}

As we have seen above, Hooke was a scientist, engineer and mechanician of genius whose researches into mekhane, or contrivance, encompassed the full gamut from the structure of living creatures to the design of sophisticated scientific instru- 
Engineering and Computational Mechanics Volume 164 Issue EM4
Dr Robert Hooke and the origins of

engineering science

Chapman ments. Yet throughout his working life, he had an active parallel interest in what might be called 'useful devices', or artefacts that made the business of life easier. I suspect that this went back to his Isle of Wight childhood, though in Oxford it clearly received a mighty boost from John Wilkins, whose Mathematical Magick (Wilkins, 1648) was presented to Hooke and exerted a profound influence on him.

Gear wheel cutting machines of sorts seem to have been in existence in August 1672, when Robert Hooke began his famous diary; some of his earliest entries mention dealing with a 'Lancashire watchmaker's son about wheel cutting engine' (see Hooke's diary entry for 16 August 1672 (Robinson and Adams, 1968) and Derham (1714: Preface, p. x.) and Gilbert (1966)). Exactly what form this machine took we do not know, but even by that date the Prescot area of Lancashire, near Liverpool, had an active cottage industry making not only complete and finished timepieces but also watch and clock parts that were exported to London by packhorse for finishing and sale. Indeed, the eminent Liverpool astronomer Jeremiah Horrocks, whose posthumous works so impressed Hooke, came from a family of rural Lancashire watchmakers, and a watch of c. 1606 by Thomas Aspinwall, Horrocks' maternal grandfather, is still preserved in the Prescot Museum (Aughton, 2004: p. 19). As London's leading mechanician and Fellow of the Royal Society, no doubt Hooke knew the leading people involved. For as we have seen, horological manufacture escalated in the seventeenth century, partly because a burgeoning rich merchant and professional class wanted elegant objects, and partly because Huygens' pendulum and Hooke's much more efficient 'anchor' escapement for pendulum clocks (1670) and his spring balance watches gave mechanical timepieces a new potential as scientific instruments in their own right.

The machine that came to be known in horological circles as the 'Hooke-type' gear-cutting machine, however, had a heavy circular brass plate, about a foot $(\approx 30 \mathrm{~cm})$ in diameter, scribed with 25 or so concentric circles around its centre pivot. Each circle was divided into a set of equidistant small holes, so that when a spring-loaded stopping pin was placed in the appropriate sequence of holes, the rotation of the plate could be divided into, for instance, 31, 78, or whatever proportion of equal parts corresponded to the number of teeth into which a clockmaker most often needed to cut clock gear wheels. When a gear-wheel blank was screwed on to the upper pivot, or arbour, on which the wheel was mounted, and a bow-and-chord or crank-handle burst of power applied to a rotary file cutter, then the spinning cutter would cut a tooth into the gear blank.

In this way, the hitherto tedious business of dividing and handfiling gears could now be handed over to an intelligent apprentice who could, if necessary, turn out dozens of precisely cut gear wheels per day. An iron and brass wheel engine from c. 1672 is preserved in the Science Museum, London, while the Museum of the History of Science in Oxford has another from c. 1700 (for early post-Hooke dividing engines see Chapman (1990b: ch. 8)). Numerous subsequent horological writers, such as Derham, discuss these engines and invariably attribute them to Hooke, though Hooke made his own invention claim in his diary in May 1674, writing that he told Thomas Tompion 'the way of making an engine for finishing wheels...' (see Hooke's diary entry for 2 May 1674 (Robinson and Adams, 1968)).

Indeed, one never needs to look far in Hooke's detailed diary, dated from 1672 to 1680 , to find him actively involved in making things with his own hands, probably in the workshop that was adjacent to his professorial rooms in Gresham College, London. In mid-March 1673, for instance, he speaks of his assistant Harry Hunt 'cleansing' the lathe and wheel-cutting machine (see Hooke's diary entry for 18 March 1673 (Robinson and Adams, 1968)), and there are other references to Hooke figuring lenses and mirrors, dividing arcs scribed into brass plates for measuring scales, or doing things with vices or files. Very clearly, philosopher and engineering scientist that he was, Robert Hooke gives in his manuscript and published writings a constant account of his personal hands-on involvement with 'contriving' devices of various kinds.

Micrographia, in 1665, and Hooke's contemporary papers in the new Philosophical Transactions of the Royal Society deal with his attempt to perfect an improved lens-grinding lathe with which to figure large object-glasses for telescopes. Like several of Hooke's inspired devices, however, the materials available and, most probably, the pivot-working techniques of the day could not take the enormous pressures involved in figuring large lenses without either seizing up or shattering (Auzout, 1665; Chapman, 2005: p. 229; Hooke, 1665: sigs. e (verso) and ee (recto)).

Then, in 1676, Hooke published a brilliant idea for making the 30,60 and $100 \mathrm{ft}(1 \mathrm{ft}=30.48 \mathrm{~cm})$ refracting telescopes of the period easier to handle by devising a series of mirrors to make the light zigzag within an oblong box and come conveniently to the eye-piece: an instrument that he called the helioscope (Hooke, 1676: pp. 4-6) (Figure 7). However, skilled optical figurer though he was, neither Hooke nor indeed any of the master opticians of the day such as Richard Reeves or Christopher Cock could work the shining speculum-metal mirrors to perfect plane surfaces, so that after multiple reflections the resulting image contained any useful information for the astronomer.

Although Hooke's interests in machine tools and practical devices covered many areas over several decades, and his designs were not infrequently too far ahead of the skills and materials of his day to be of immediate advantage, some of them were to win enduring places in the annals of mechanical technology. And in this respect nothing springs more quickly to mind than Hooke's celebrated universal joint (Hooke, 1676; Mills, 2007). While this inspired essay in kinematics is now routinely used in all manner of power-transmission systems, it first made its public appearance in 1676 when Hooke employed the now familiar arrangement of 


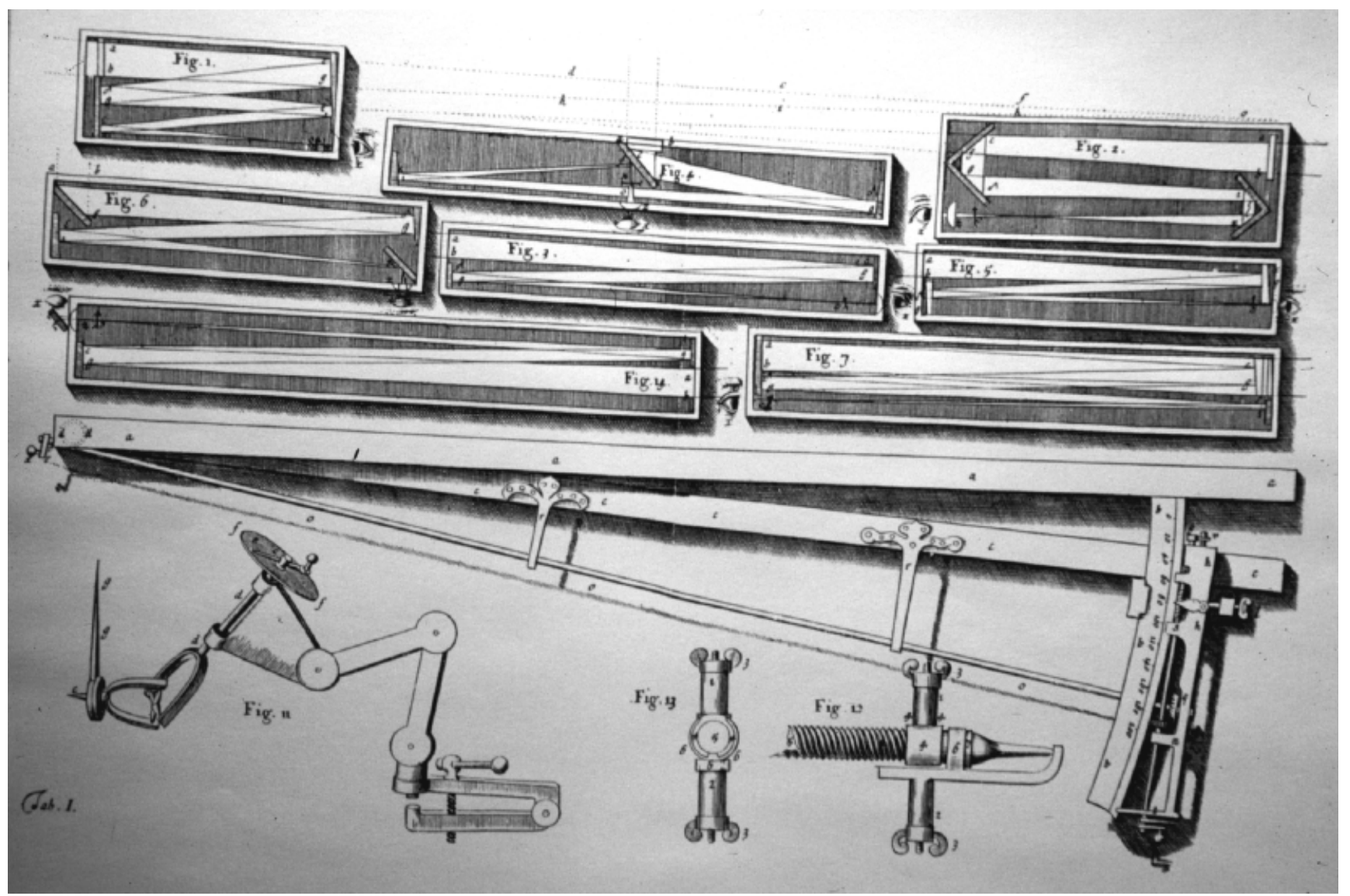

Figure 7. Universal joint, used to move a pointer around a graduated scale. Part of Hooke's design for making long telescopes more compact by trains of collimated mirrors and lenses (Hooke, 1676)

internally cross-pivoted 'horseshoes' to transmit gentle handcontrolled energy down a metal shaft, and round a flexible joint, to read off angular quantities on a calibrated scale by means of a pointer. Similarly, his posthumously published device for collecting specimens from the seabed and related materials from great depths by means of spring-loaded vessels has, in its modern form, become a useful tool for the oceanographer (Derham, 1726: Table 1). Indeed, one could write a whole article on the machine tools and practical contrivances appearing in Hooke's published and manuscript works.

\section{Catenary arches and civil engineering}

Following the Great Fire of 1666, Robert Hooke was appointed Surveyor to the City of London, shortly before his close friend and fellow physical scientist, Dr Christopher Wren (knighted 1673), was appointed Surveyor to the King. In this new job which made Hooke, like Wren, one of the foremost civil engineers in Britain - he became responsible for the rebuilding of a new, and hopefully fireproof, capital city. Hooke's responsibility was for all new houses, commercial premises, and professional and charitable buildings, while Wren's duty of care covered all the royal fabrics, most notably the palaces and city churches. In 1667, both Hooke and Wren also held academic chairs in mathematics and astronomy respectively. Hooke was Professor of Geometry at Gresham College, London, while Wren held the Savilian Astronomy Professorship at Oxford. Neither had been trained in architecture or building, though as academic mathematicians and scientists with established reputations as practical men of good taste and artistic talent who fully understood the architecture of both classical and Renaissance Europe, they would have seemed a natural choice to contemporaries. Several modern scholars have written on Hooke's architectural and building work (e.g. Chapman, 2005: pp. 120-134, footnotes and bibliography). The foremost contemporary scholar in this field is Professor Michael Cooper (e.g. Cooper, 2003b).

Hooke's diary for $1672-1680$ brings home to us how closely the two men worked together on both royal and city projects. So closely, in fact, that some modern architectural historians even assumed Hooke to have been Wren's assistant! However, while most of Wren's churches survive (if only, in some cases, as postWorld War II shells), only one of Hooke's city of London 
Engineering and Computational Mechanics Volume 164 Issue EM4
Dr Robert Hooke and the origins of

engineering science

Chapman constructions still exists, although some did remain long enough to be photographed. Hooke's majestic lunatic asylum Bethlehem (Bedlam) Hospital, his sumptuous Royal College of Physicians building in Warwick Lane with its fine dome and lecture theatre (both, at least, recorded in fine art engravings), Montague House on the site now occupied by the British Museum and many more have all gone. Only his spectacular $202 \mathrm{ft}(61.6 \mathrm{~m})$ high Fire 'Pillar' near London Bridge survives, along with that gem of a red-brick Dutch-style church designed for his old headmaster Dr Busby, at Willen, now part of greater Milton Keynes. The Fire Pillar (more commonly known as The Monument), built exactly $202 \mathrm{ft}$ from the precise spot where the Great Fire started, was not only an astonishing piece of civil engineering in its own right but was also designed to act as a scientific instrument. Its hollow stone shaft was intended to accommodate a long-focus objectglass or zenith sector telescope with which Hooke hoped unsuccessfully, as it transpired - to measure the annual parallax of the zenith star Gamma Draconis as a way of obtaining a physical proof of the Copernican theory. Nevertheless, its $202 \mathrm{ft}$ vertical rise provided opportunities for studying differences in barometric pressure between the top and bottom of the column, as he recorded in his diary entry of 16 May 1678 (Robinson and Adams, 1968). Hooke found that the mercury in his barometer registered one-third of an inch $(\approx 8.5 \mathrm{~mm})$ less at the top of the Monument column than it did at the bottom. These barometric researches, concerned as they are with the changing pressure relationship acting between the 'elastic fluid' (air) and the dense fluid (mercury), might be seen as initiating the science of fluid mechanics.

Without doubt, architecture and town planning made Hooke's substantial fortune (as they also helped augment that of Wren), but what concerns us here is Hooke the civil engineer. For Hooke, it seems, could undertake no task without seeing new forces of nature and mathematical or experimental principles at work. On a more workaday civil engineering note, however, he mentions numerous meetings with contractors, church wardens, city dignitaries and private patrons regarding building and engineering work. In his diary entry for 9 March 1676, for example, he 'Agreed with Cartwright for Bow Tower for £2550' (Robinson and Adams, 1968).

Hooke's outstanding contribution to civil engineering grew as an offshoot from his fascination with elasticity, compression and motion: this was the catenary arch. Indeed, without this mathematical and physical form, his friend Wren would have had far more difficulty in crowning St Paul's Cathedral with its dome. Hooke first began to work on the problems of the catenary arch - the curved shape produced when a chain (Latin catena) or rope is suspended between two points - in the summer of 1675. At the same time, in fact, that he was working on the isochronal properties of curved hairsprings for watch escapements.

On 26 September 1675, he expressed in his diary (Robinson and Adams, 1968) the first recorded formulation for the geometry of a catenary arch: 'pendet continuum flexile, sic stabit grund rigidum' (the curved line hangs [flexibly], and thus the foundations [or supports] will stand firm). This is assuming that he is using the word grund in the same sense as the medieval dogLatin word grundo, 'to lay a foundation'. However, soon after, Hooke construed it as the now classic if slightly differently expressed formulation of the Linea Catenaria: 'Ut pendet continuum flexile, sic stabit contiguum rigidum inversum' or 'As the curved line hangs [flexibly], so the adjacent [line or curve] will stand rigid upside down [or upon its supports]' (Waller, 1705: p. xxi).

The catenary was an 'invention' of which Hooke was especially proud, it being a purely intellectual discovery in geometry - the subject in which he held his academic chair - but one that nonetheless teemed with practical possibilities. Deriving from their mathematical properties, catenaries had invaluable loadbearing potential and, as mentioned earlier, were used by Wren to help direct the weight and thrust created by the outer and inner domes of St Paul's. Indeed, it may have been to this very possibility for the as-yet-on-the-drawing-board cathedral that Hooke somewhat obliquely alluded in his diary entry of 4 September 1679 (Robinson and Adams, 1968), writing that he 'Walkd with Sir Chr. Wren in the Park, told him of double vaulting Paules with cramps between'. It seems as though Hooke had already discussed the potential of catenary arches with a $\mathrm{Mr}$ Fitch (elsewhere described as 'Controuler' (Bennett, 2003: p. 187)) and Wren, writing in his diary for 5 June 1675 'He [Wren?] promised Fitch at Paules. He was making up my principle about arches and altered his module by it' (Robinson and Adams, 1968).

Translating seventeenth century anagrams is never straightforward, even when the author subsequently provides a key. In this instance, it is not obvious which words are nouns, which are adjectives and which are adverbs. Indeed, we may now find it odd that three centuries ago a major discovery in science should have been published in an obscurely encrypted form and left that way for several years, giving the philosophers of Europe ample time to wrestle with it before the discovery was revealed in still oblique Latin prose. Yet seventeenth century scholars clearly loved such brain teasers, and scientists of the calibre of Galileo, Huygens and Hooke used them to the delectation, or annoyance, of their readers. Just imagine how modern scientists would respond if their colleagues announced important discoveries in chains of Sudoku puzzles encrypted into Roman numerals!

Judging from his writings, however, I suspect that Hooke would have seen his work as a civil engineer as very much of a piece with his work on horological mechanics, on the physiology of living organisms and on those barometric forces that seemed to produce the weather. For whether he was planning a new deep foundation, trying to offset the thrust of a dome or a steeppitched roof, or finding an engineering application for a beautiful catenary curve, he would have seen himself as dealing with those 
universal properties of elasticity, spring, compression and reflux that he saw as pervading the entire realm of nature.

\section{Conclusion}

While it cannot in any way be claimed that Robert Hooke was the first Oxonian to be an ingenious contriver, a certain set of circumstances had come together by the mid-seventeenth century to make him a figure of unique and exceptional standing. Of course, there was Hooke's own peculiar genius of mind, with all its many facets of scientific pragmatism, visionary imagination, manual dexterity and lucidity as a communicator. But there was also a cultural sea-change going on in various places across Europe, notably in Oxford during the 1650s and then in London from the 1660 s onwards.

At the heart of this sea-change was a new vision of nature at all its levels - as a machine that could be researched by means of increasingly sensitive 'artificial organs' to enhance human perception, and then tested, pinned down and comprehended by rigorous experimental technique and the use of mathematics. And no one embodied this vision more powerfully, pursued it more vigorously or attempted to harness its fruits for 'the Relief of Man's Estate' more ingeniously than did Robert Hooke. For over his 40-year career, in Oxford and in London, Robert Hooke abundantly demonstrated that the new experimental science really did work and could be made to produce a seemingly endless stream of discoveries, insights and useful devices. In the way that he almost routinely brought together the 'philosophical' insights of the pure scientist and the contrivance of original devices, this 'Greatest Mechanick' in the world became Oxford's first engineering scientist.

\section{Acknowledgements}

I wish to acknowledge my wife Rachel, a classicist, for her assistance and advice on the interpretation of Hooke's two anagram keys for the catenary curve. I was graciously permitted by Messrs Bonham of London to spend 5 hours examining the Hooke manuscript on 13 February 2006. The Hooke manuscript has subsequently been transcribed by a team of scholars for the Royal Society and is now available online at http://royalsociety.org/ Hooke-Folio.

\section{REFERENCES}

Aubrey J (1689) Robert Hooke. In Brief Lives (Dick OL (ed.)), 3rd edn. Secker and Warburg, London, 1949.

Aughton P (2004) The Transits of Venus. The Brief, Brilliant Life of Jeremiah Horrocks, Father of British Astronomy. Windrush Press, London.

Auzout A (1665) Considerations of Monsieur Auzout upon Mr Hook's new instrument for grinding optick-glasses.

Philosophical Transactions 1(4): 55-63.

Bacon F (1620) Novum Organon. Apud J. Billium, London.
Bacon F (1627) Sylva Sylvarum, or, a natural history in ten centuries. William Rawley, London.

Bennett J (2003) Hooke's instruments. In London's Leonardo. The Life and Work of Robert Hooke (Bennett J et al. (eds)). Oxford University Press, Oxford, pp. 63-104.

Birch T (1756) History of the Royal Society of London III. Printed for A. Millar, London.

Boyle R (1660) New Experiments Physico-Mechanical, Touching the Spring of Air, and its Effects (Made, for the most Part, in a New Pneumatical Engine) Written by Way of Letter to the Right Honorable Charles Lord Viscount of Dangarvan, Eldest Son to the Earl of Cork. H. Hall, Oxford (1662 edition, pp. 40-50).

Boyle R (1670a) The continuation of the experiments concerning respiration... Philosophical Transactions 5(62): 2011-2031.

Boyle R (1670b) The continuation of the experiments concerning respiration... Philosophical Transactions 5(63): 2035-2056.

Britten FJ (1986) Britten's Old Clocks and Watches and their Makers, 1894, 1899. Methuen, London.

Chapman A (1990a) George Graham and the concept of standard accuracies in instrumentation. Bulletin of the Scientific Instrument Society 27: 3-8.

Chapman A (1990b) Dividing the Circle. The Development of Critical Angular Measurement in Astronomy 1500-1850. Praxis-Wiley, Chichester.

Chapman A (1991) 'A World in the Moon': John Wilkins and his lunar voyage of 1640. Quarterly Journal of the Royal Astronomical Society 32(2): 121-132.

Chapman A (1994) John Wilkins and the experimental philosophy at Wadham. In Wadham College (Davies CSL and Garnett J (eds)). Wadham College, Oxford, pp. 24-35.

Chapman A (1996) George Graham and the concept of standard accuracies in instrumentation. In Astronomical Instruments and their Users (Chapman A (ed.)). Variorum, Aldershot.

Chapman A (2005) England's Leonardo: Robert Hooke and the Seventeenth-Century Scientific Revolution. IoP Publishing, Bristol.

Cooper M (2003a) A More Beautiful City. Robert Hooke and the Rebuilding of London after the Great Fire. Sutton Publishing, Stroud, pp. 36-40.

Cooper M (2003b) Hooke's career. In London's Leonardo. The Life and Work of Robert Hooke (Bennett J et al. (eds)). Oxford University Press, Oxford, pp. 28-49.

Derham W (1714) The Artificial Clockmaker. A Treatise of Watch and Clock-work. Printed for James Knapton, London.

Derham W (ed.) (1726) Of the Invention of the Barometer in the Year 1659, Philosophical Experiments and Observations of the late Eminent Dr Hooke. Printed by W and J Innys, printers to the Royal Society, London.

Dickens C (1850) Household Words 10: 222-225.

Digges L (1571) Pantometria. Printed by Abell Jeffes, London.

Edinburgh Review (1850) CLXXXIV: 299-356.

Gibbs-Smith CH (1962) Sir George Cayley's Aeronautics, 17961855. HMSO, London.

Gilbert KR (1966) The Machine Tools Collection: Catalogue of 
Exhibits with Historical Introduction. HMSO, London, 1966, p. 70 , item 170, Wheel-cutting Machine, seventeenth century, plate 18.

Greaves J (1646) Pyramidographia, or a description of the Pyramids in AEgypt. Printed for George Badger, London.

Hooke R (1665) Micrographia, or Some Physiological Descriptions of Minute Bodies Made by Magnifying Glasses. Printed by John Martyn and James Allestry, on behalf of the Royal Society of London.

Hooke R (1666) Philosophical Transactions 1: 218-119.

Hooke R (1667) Undated manuscript. Royal Society MS Classified Papers XX(54).

Hooke R (1671) An experiment to prove that the substance of a candle or lamp is dissolved by the air, and the greatest part thereof reduced to a fluid, in the forme of air. Shewd the $R$. Society 22. 29 Febr. 1671, Royal Society MS [RBC. 3. 201], pp. 201-203.

Hooke R (1675) Wilkins's flying at Oxford. Diary 11 February 1675.

Hooke R (1676) A Description of Helioscopes; And Some Other Instruments. London.

Hooke R (1677) Lampas; or Descriptions of some Mechanical Improvements of Lamps and Waterpoises. Together with other Physical and Mechanical Discoveries. Printed for John Martyn, London, pp. 4-8.

Hooke R (1678) Lectures De Potentia Restitutiva, or of Spring Explaining the Power of Springing Bodies. Printed for John Martyn, London.

Hooke R (1686) Philosophical Transactions 116(185): 241-244.

Huygens C (1658) Horologium. Latin facsimile and English translation in (1970) Antiquarian Horology 7(1): 35-54.

Kent P (2005) Hooke's early life at Oxford. In Robert Hooke and the English Renaissance (Kent P and Chapman A (eds)). Gracewing, Leominster, pp. 39-64.

Latham R (ed.) (1986) The Shorter Pepys. Guild Publishing, London, p. 649.

Maddison REW (1969) The Life of the Honourable Robert Boyle F.R.S. Taylor \& Francis, London.

Mills A (2007) Robert Hooke's 'universal joint' and its application to sundials and the sundial-clock. Notes and Records of the Royal Society 61(2): 219-236.

Newton I (1671) A Letter of Mr Isaac Newton. .., containing his new theory about light and colors... Philosophical Transactions 80(6): 3075-3087.

North JD (2005) God's Clockmaker. Richard of Wallingford and the Invention of Time. Hambledon and London, London.

Pledge HT (1966) Science Since 1500. HMSO, London. Robinson H and Adams W (eds) (1968) The Diary of Robert Hooke M.A., M.D., F.R.S., 1672-1680. Taylor \& Francis, London.

Shapin S and Schaffer S (1985) Leviathan and the Airpump: Hobbes, Boyle and the Experimental Life. Princeton University Press, Princeton, NJ.

Spedding J, Ellis RL and Heath DD (eds) (1876) The Works of
Francis Bacon, Vol. II, The Philosophical Works. Longman, London.

Sprat T (1667) Method of making a history [Record] of the weather by Mr Hook. In A History of the Royal Society, for the Improving of Natural Knowledge. Printed by William Morrice, London, pp. 173-179.

Thompson D (2007) Watches in the Ashmolean Museum. Ashmolean Museum, Oxford.

Waller R (ed.) (1705) The Posthumous Works of Robert Hooke M.D.S.R.S. Containing his Cutlerian Lecture and other discourses. Richard Waller for the Royal Society, London.

Wilkins J (1638) Discovery of a New World. . in the Moon. London. Wilkins J (1648) Mathematical Magick, or the Wonders that may be performed by Mathematical Geometry. London.

Wilkins J (1802) The Mathematical and Philosophical Works of the Rt. Rev. John Wilkins. Vernor and Hood, London.

Willis T (1664) Cerebri Anatome: cui accessit nervorum description et usus. Printed by John Martyn and James Allestry, London. English translation by S Pordage, 1681, London; facsimile of the English edition by Samuel Pordage, Montreal, McGill University Press, 1965.

Worcester, Marquis of (1663) Century of Inventions. London. Wright M (1989) Robert Hooke's longitude timekeeper. In Robert Hooke. New Studies (Hunter M and Schaffer S (eds)). Boydell Press, Woodbridge, pp. 63-118.

\section{WHAT DO YOU THINK?}

To discuss this paper, please email up to 500 words to the editor at journals@ice.org.uk. Your contribution will be forwarded to the author(s) for a reply and, if considered appropriate by the editorial panel, will be published as a discussion in a future issue of the journal.

Proceedings journals rely entirely on contributions sent in by civil engineering professionals, academics and students. Papers should be 2000-5000 words long (briefing papers should be 1000-2000 words long), with adequate illustrations and references. You can submit your paper online via www.icevirtuallibrary.com/content/journals, where you will also find detailed author guidelines. 